\title{
Varejo: ganhos e perdas
}

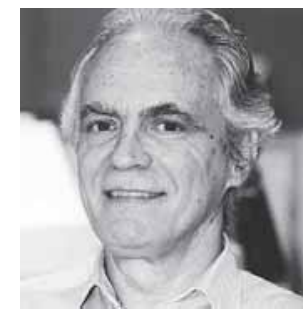

Paulo H. Sandroni FGVEAESP

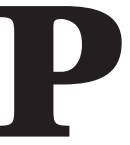

rodução e consumo, ou consumo e produção? Bem, dá no mesmo. Ou quase. Se para consumir é preciso antes produzir, a produção também requer o consumo de fatores: mão-de-obra, matérias-primas etc. É o chamado consumo produtivo. Mas estamos falando do consumo final, momento no qual o produto desaparece no estômago ou na fantasia de quem 0 adquiriu.

Em uma economia de mercado (em uma tribo é diferente, ou pelo menos era...), esta passagem ocorre por meio de atos de compra e venda e o dinheiro está aí para facilitar as coisas. $\mathrm{O} u$, às vezes, para dificultar, quando prima pela ausência. A essa etapa se dá o nome de varejo.

Quanto mais eficaz a passagem do produto ao consumidor final, isto é, quanto menos esforço uma sociedade necessitar para essa metamorfose, maior será seu bem-estar. Nos últimos tempos, imensos avanços foram realizados no setor: novos layouts das lojas, ousadas embalagens, logística primorosa e principalmente a revolução da informática.

Apesar desses avanços, permanece a pergunta intrigante: 0 simples ato de comprar e vender agrega valor a um produto? À primeira vista, não: na prateleira do supermercado ou nas mãos do consumidor o produto é o mesmo. Ainda que antes seja valor de troca e em seguida valor de uso. Mas, olhando o processo como um todo, as coisas mudam. Se considerarmos o tempo necessário para que o produto acabado passe às mãos do consumidor final, a resposta pode ser diferente. Q uanto menor for, maior será o giro do capital. Um mesmo capital de giro realizará um maior valor de vendas. 0 lucro das empresas envolvidas tenderá a ser maior. E diante de custos menores (se houver concorrência sadia), esse aumento de "produtividade" - ou parte - poderia ser repassado aos consumidores finais.

Uma questão, no entanto, conspira contra a redução desse tempo nas grandes cidades: 0 caos do seu crescimento e a dupla transporte-trânsito cada vez mais complicada e custosa. A generalização do just in time, também na esfera da circulação faz com que os estoques tendam a se transformar em fluxos. As prateleiras enchem e esvaziam-se continuamente, e os estoques de muitos pontos-devenda estão "permanentemente na rua". Ora, o trânsito já emperrado tende a piorar e acaba sendo o verdugo de todos nós. Os custos de ressuprimento aumentam e dois fenômenos perturbadores entram no nosso cotidiano: motoboys e helicópteros.

É possível que parte dos ganhos que o varejo vem obtendo ultimamente na logística, no marketing, na administração de pessoas, no layout das lojas e no controle de estoques, se perca no torvelinho destas deseconomias externas. 